\author{
УДК 327. 351 \\ JEL M10, F42 \\ DOI https://doi.org/10.17721/tppe.2021.42.14
}

\author{
Bülent Açma, Professor, \\ Department of Economics, \\ Anadolu University, Eskisehir Turkey \\ Tekang P. Kwachuh, PhD Student, \\ Department of Political Science and \\ International Relations, \\ Anadolu University, Eskisehir Turkey
}

\title{
TURKISH PUBLIC DIPLOMACY IN A DECADE: AN APPRAISAL AND PROSPECTS
}

The birth of nation-states after the Westphalian Treaty of 1648 signaled the dominance of states in international relations. The end of WW1 and especially WW2 precipitated a paradigm shift in global affairs with the world driven by superpower rivalry between the U.S and USSR in what became known as the Cold War. The birth of the modern-day Republic of Turkey in 1923 as a remnant of the defunct Ottoman Empire has emerged as one of the most successful states whose geostrategic position is a huge advantage in her public diplomacy, making maximum use of her soft power rather than hard power. This paper dwells on those institutions that are pivotal in catapulting Turkish public diplomacy specifically from 2010 to mid-2021. Also, this work sought to look at recent wins within 10 years of Turkish Public Diplomacy and it pays attention to the backlashes and prospects of Turkish Public Diplomacy. This paper found out that a significant institution heralding Turkey's Public Diplomacy is the Turkish Ministry of Foreign Affairs and the prestigious Turkish Government scholarship scheme stands out to be one of the big wins for Turkey. A huge deficit to Turkish Public Diplomacy hangs on insecurity across its borders. Lastly, an envisaged prospect can be spotted with the rising competitive nature of TRT World on the global media landscape. This paper concludes that Ankara's public diplomacy would be more robust prior to the Centenary of its Independence in 2023 based on its institutions, recent gains and foreign policy goals.

This article has penned down those institutions that are manning Turkish Public diplomacy such as YEI, TIKA, YTB etc., it made an appraisal on Turkish public diplomacy within a decade bringing to light past, contemporary gains and shortcomings as well. The paper then evolved around the prospects that await Turkish public diplomacy ahead of the 2023 Centenary Independence Celebration citing the role of TRT World as an important player in this expectation. It is pivotal to consider that for public diplomacy to be considered successful, soft power should be accompanied by economic prowess that will metamorphose into vibrant persuasive power. Within a decade, Turkish public diplomacy seems to have witnessed low and high tides however it keeps maturing as the years unfold. There is no doubt that the JDP leadership, institutions and actors in Ankara's public diplomacy initiative from 2010 should be applauded for haven nurtured and implemented its public diplomacy after ascending power not focusing solely on the Middle East but has mapped out other regions globally, harvesting excellent results and off course thanks to the "Strategic Depth" Doctrine of Foreign Minister Davutoglu that Turkey has now mastered the public diplomacy terrain and has a great interest page in dominating global public diplomacy arena with little or no resistance from other states, particularly in an unpredictable MENA Region.

Keywords: Appraisal, Soft Power, Public Diplomacy, Prospect, Turkey. 
Problem statement. The spread and global usage of political terminologies such as globalization, Responsibility to Protect, Clash of Civilizations etc., are fathered by a person or group of persons. The birth of nation-states after the Treaty of Westphalia of 1648 and the conduct of international relations has metamorphosed to include aspects of public diplomacy via soft power since the world entered an era of complex interdependence. We are presently witnessing an era in which America and western hegemony over public diplomacy and the use of soft power is drawing to a close. The concept of public diplomacy has become a buzzword in the diplomatic landscape and Foreign Offices in all States and one architect whose contribution navigated what we now sing today as "Public Diplomacy" was Edmund A. Gullion, the former Director of the US Information Agency (USIA) in 1965, thus, Joseph Nye, the Father of soft power and co., followed diligently in their writings providing a holistic nexus of public diplomacy and soft power alongside their tenets.

Edmund A. Gullion, the former Director of the US Information Agency (USIA), first used the concept of public diplomacy in its modern sense in 1965. According to Gullion, "Public diplomacy deals with the influence of public attitudes on the formation and execution of foreign policies. It encompasses dimensions of international relations beyond traditional diplomacy; the cultivation by governments of public opinion in other countries; the interaction of private groups and interests in one country with another; the reporting of foreign affairs and its impact on policy; communication between those whose job is communication, as diplomats and foreign correspondents; and the process of intercultural communications" (www.uscpublicdiplomacy.org).

Bibliography Analysis. The concept of "soft power" was first developed by Joseph S. Nye, a Harvard University Professor, in his article "Soft Power" published in Foreign Affairs in 1990 and his book, "Bound to Lead: The Changing Nature of American Power." According to Nye, soft power is "the ability of a country to persuade others to do what it wants without force or coercion." Nye, developed the concept of soft power to counter the claim that American power has weakened since the 1970s and that, in fact, it has already begun to decline. According to Nye, first of all, the power of the USA should not be considered only in a military sense but also in an economic sense. The main hegemonic power of the US originates from its soft power. He claims that the soft power of the United States consists of its universal values, attractive lifestyle, institutions, policies, culture, and ideology.

The purpose of the article is to study Turkish public diplomacy in a decade and to indentify an appraisal and prospects.

Research Results. According to Nye, "soft power is the ability to affect others to obtain the outcomes one wants through attraction rather than coercion or payment. A country's soft power rests on its resources of culture, values, and policies. A smart power strategy combines hard and soft power resources. Public diplomacy has a long history as a means of promoting a country's soft power and was essential in winning the Cold War" (Nye, 2008). From an analytical lens of Nye, hitherto, the postulation of soft power touch on carrot policy, not on stick policy. It embraces glamour, seduction, and makes countries' to be envied by other states. In this light, Nye unyokes soft power from military-economic power, which is anchored on threats and which is wrapped in the fabrics of hard power. Public 
Diplomacy emerged during the Cold War as a tool for "direct communication with foreign peoples, with the aim of affecting their thinking and ultimately that of their government" (Handelman, 2012: 166). The United States and the Soviet Union "primarily used international broadcasting" in establishing their channels of "information and persuasion campaign" (Gilboa, 2008: 59). The bipolar standoffs between the USA and USSR and the malignant havoc that utilization of nuclear arsenals could bring upon them, signaled that propaganda campaigns during these periods were solid and effective devices for fabricating advantageous position amid the citizens of the great-powers.

The birth of the modern-day Republic of Turkey in 1923, as a remnant of the defunct Ottoman Empire has emerged as one of the most successful states whose geostrategic position is a huge advantage in her public diplomacy, making maximum use of her soft power rather than hard power. Thus, the United States and other European States can no longer lay claim on solely heralding public diplomacy at the expense of other states in meeting their foreign policy goals globally since other states like Turkey now master the arts and sciences of robustly executing public diplomacy.

The crafting, implementation and evaluation of public diplomacy is usually executed by actor(s) emanating from institutions and the party or government in power is wholly responsible for its public diplomacy's status and prestige on a global sphere. In this light therefore, the present government in power the Justice and Development Party (JDP) in Turkey has been at the driver's seat in chartering the contours of Turkish public diplomacy making judicious use of Turkey's soft power via discourses and lofty programs. Ekşi (2018: 266) purports that, the soft power capacity and the theoretical background of the JDP governments' foreign policy is derived from history, culture, Islamic references of the ruling elite, the geography (the Ottoman Empire region), and more strictly speaking, former Minister of Foreign Affairs Ahmet Davutoğlu's formulation of foreign policy, which is sometimes referred to as the "New Ottomanism." It should be succinctly clear that the application of contemporary and procedural public diplomacy in the foreign policy and public diplomacy of Turkey hangs on the shoulders of the Justice and Development Party (JDP) messianic ascension to power in the 2000s.

The JDP's stratagem of self-styling itself as a blueprint globally and in the MENA region distinctively, in addition to Ankara's occupying the $11^{\text {th }}$ position on the world global economic ranking system stems from its leaping trading and commercial apparatuses, demanding her to utilize public diplomacy tools thus spending huge amount of dollars is un-avoidable. The new vision and identity of the JDP leaders ruling the country in the 2000 s was effective while Turkey shifted for the first time to the soft power and public diplomacy in foreign policy in a modern and institutional manner. The identity of the JDP that originates from the National Outlook tradition (Milli Görüs), which is an Islamist movement, is one of the most significant characteristics of the ruling party that distinguishes it from the previous parties with strict secular identity (Ekşi and Erol, 2019: 4). The main reason for implementing the public diplomacy policy during the JDP government was the desire of the new government to explain itself to the world with respect to its new ideology. The ruling government considered itself to be different from the former governments that had a firm focus on secularism, military and security (Ömer, 2012). It was a strategic choice to use 
public diplomacy policy in order to explain to the world its moderate Islam model with softened secularism that embedded neoliberal capitalist economy. Another essential reason for implementing public diplomacy policy was the ambition of the JDP leaders to make Turkey a regional power and global actor (Ekşi and Erol, 2019: 14).

The mission of this article was aimed at $x$-raying those institutions that are heralding Turkish public diplomacy specifically from 2010-mid 2021. The paper moved forth in painting events that signaled big wins in Ankara's public diplomacy within a decade and the article settles on a few factors that impedes Turkish public diplomacy and it makes a forecast on Turkey's public diplomacy especially within the rubrics of TRT World's role, winning hearts and minds for Ankara globally.

1. What are all these Lullabies about Public Diplomacy and Soft Power?

On Public Diplomacy

Since the birth of the concept of Public Diplomacy, the term has evolved from one epoch to another providing vast definitions from both scholars and public diplomacy practitioners.

According to the Murrow Centre, one of its previous brochures, described public diplomacy as follows: "Public diplomacy has to do with the influence of public attitudes on forming and executing foreign policies. Dimensions of international relations are extended beyond traditional diplomacy, cultivation of public opinion with governments in other countries, interaction of private groups and interests in a country with those of another one, reporting of the foreign (affairs) works and its impact on the policy, communication among them, communication among diplomats and foreign correspondents, and inter-cultural communication processes" (Snow, N., and M. Taylor, P., 2008: 19 as cited by Bekim et al., 2013: 1). In a public diplomacy arena, transnationalism, ideals, ideas and availability of news are delicate in the entire procedural manner and often than not its mandated in aiding democratic reign, build-up economic status and guarantee mass solace.

Two main factors are critically important in public diplomacy in global politics. The first one is that states have made gaining the support of public opinion a foreign policy aims due to the importance of the social dimension in global politics. In this context, gaining the support of public opinion refers to a state's having and exerting soft power. This is because the increasing importance of societies has made it necessary for states to win the public opinion, along with the representatives of states, for their cause. In classical diplomacy, only winning the representatives of states would be seen as adequate for their cause. Secondly, the visualization of everyday life by the information and communication technologies has brought about the phenomenon of visibility in foreign policy. In global politics, this has made it necessary for states to present their policies with an attractive visual image in an attempt to carry them out successfully. Moreover, it has brought the necessity of presenting not only the policies but also the actors themselves with an attractive image to the public and the international community. What became gradually important is not the successfulness of a state's foreign policy, but the execution of this policy and the concepts it communicates as well as the representation of these concepts in the international press and social media. As these two main factors increased the importance of public diplomacy in global politics, especially in the 2000s, states intensified their public diplomacy practices (Ekşi, 2019: 177). The role of diplomacy to improve the 
country's international image is directly a matter of public diplomacy, which makes this work with its instruments, such as public relations and media (Bekim et al., 2013: 1).

The favourable opinion of a nation is fundamental as "public diplomacy above all thrives in highly interdependent regions and between countries that are linked by multiple transnational relationships and therefore a substantial degree of interconnectedness' between their civil societies" (Melissen, 2005: 11). It is in this light that, countries strive to autonomously seek economic and military prowess aimed at image refinement on a global landscape. Bekim et al., 2013: 1), states that; the most important is that to be an important country you should create attention in the international arena, while the attention makes you famous, and at the moment you create an attention, we must be careful that how much positivity, sustainability and potential such attention presents. Public diplomacy gadgets in today's era consist of; a vibrant media both virtual, audio virtual and print, organization of interesting cultural activities at home and abroad, catchy touristic sites and packages and a lot more. For example., transmitting musical and art fairs via the television and other social media outlets organized by Turkey is another landmark in her public diplomacy and the crafting of gigantic programs sponsored by Turkish agencies. The primary goal is to achieve and win the hearts and minds of global audiences and those benefitting from such programs thus promoting her image.

Deficient communication has minimal or no effect on the populace, especially on issues surrounding high and low politics which could be political and economic inclined. In drafting a public diplomacy agenda which are politically oriented, there is a need for critical thinking which brings together an interlocutor of wider views focusing on essential issues. The Media as a tool, from a starting point, has given birth to novel social movements with varied interests which are either individualistic or broader in nature. The heed concerning public diplomacy and engagements, are accentuated and re-accentuated as a gateway with efficient usage of sophisticated technologies in delivering information, ideals and ideas via the media, newspaper, television, internet and other digital tools, are "revolutionizing" as public diplomacy evolves systematically. The motive of communication in quintessence is that it should reach a great number of audience and win their hearts and minds.

On Soft Power. Nye (2008: 94) defines soft power as "the ability to affect others to obtain the outcomes one wants through attraction rather than coercion or payments". This approach to diplomacy presents the opportunity for a change from "traditional governmentto-government diplomacy toward a government-to-citizen perspective" (Golan, 2013: 1251) characterized by a two-way engagement. Hard power uses "military and economic resources" whereas soft power might "include culture, values and policies" (Roselle et al. 2014: 73). The potential for the attractiveness of soft power rests on whether the target finds it appealing. According to Nye soft power can be constructed so it will serve the interest of that State. He argues, for example, that Governments should pay the same great deal of attention to justify and explain their decision to foreign populations as they do for their domestic (Nye, 2008: 101). Or, that public diplomacy should aim for "the development of lasting relationships with key individuals over many years through scholarships, exchange, seminars or conferences" (Nye, 2008: 102). These practices help 
to "create an attractive image of a country" (Nye, 2008: 102) and consequently higher rate of success for its policies.

The Justice and Development Party (JDP) government began to implement diplomacy within the framework of the diversification of Turkish foreign policy and also initiated soft power policy to enhance Turkey's influence in the Balkans, Caucasia, Central Asia, Africa, and the Middle East. Furthermore, the JDP leaders' desire to become a regional power and the leader of the Middle East and Muslim world played the main role in adopting public diplomacy and soft power policies (Traub, 2011 as cited by Ekşi and Erol, 2018: 2). Affirmatively, the foreign and public diplomacy of Ankara has been configured to take into account the nexus of historical, cultural and communality facets and tools.

2. Institutional Scaffoldings of Turkish Public Diplomacy (TPD)

A Novel Era in Turkey's Public Diplomacy

Turkish public diplomacy within a decade has passed from thin and thick lanes and metamorphosed systematically accruing from the birth of a series of holistic institutions and the recalibration of existing structures that were at the forefront of the Turkish public diplomacy at infancy. This part of the article is pinned on x-raying those institutions which have and are playing a pivotal role in catapulting Ankara's global image as seen in their actions.

Büyüktanır (2018: 75-77) stated that public diplomacy institutions are the new actors in Turkish foreign policy and they have served as the new channels and mechanisms for defining and implementing the recent policies. These new institutions have established the civilian aspect of Turkish foreign policy that helps conduct public diplomacy through softpower activities from a social perspective rather than through policy practices of a hardpower approach. The newly established public diplomacy institutions are also a product of the restructuring of the Ministry of Foreign Affairs. Hence these institutions work in cooperation with the new units established within the Ministry of Foreign Affairs to adapt Turkish foreign policy to the international milieu. The Ministry of Foreign Affairs has been reorganized within the framework of public diplomacy, which also has aimed to make the Ministry compatible with the redesigned foreign policy formulation and the changing global system. These transformations within the Ministry and in Turkish foreign policy have been brought about substantially by the JDP and its political vision (Ekşi, 2019: 179).

In addition, the JDP leaders perceived the importance of public diplomacy in the 21 st Century global politics and instituted to build the public diplomacy and soft power of Turkey for the first time within the framework of the public diplomacy policy at an institutional level in the second period of their government. In this context, new institutions like the Presidency of the Office of Public Diplomacy (KDK), Yunus Emre Institute (YEI), The Presidency for Turks Abroad and Related Communities (YTB) were established and the institutions such as the Ministry of Foreign Affairs and Turkish Cooperation and Coordination Agency (TIKA) were reorganized within the context of public diplomacy. As such, these new institutions became the new channel and mechanisms of the Turkish Foreign Policy (TFP) and diversified it with respect to instruments, actors and methods. Furthermore, social and cultural components were added to the TFP, in addition the JDP government made the TFP multidimensional (Ekşi and Erol, 2018: 14). A new era for 
Ankara is highly visible in the dispatching of her global public diplomacy agenda. According to Ekşi and Erol (2019: 14), Turkey started to implement the public diplomacy policy very late compared to the Western countries like the U.S., England, and Germany. Although the soft power and public diplomacy activities were being performed under the leadership of TIKA towards the countries of Caucasia and the Middle East after the collapse of the USSR in 1991, it was the JDP government that employed public diplomacy as a policy in the 2000s.

The Presidency of the Office of Public Diplomacy

The Prime Ministry Public Diplomacy Coordination Office (KDK) was established to provide coordination between the state institutions that perform soft power activities like the Ministry of Foreign Affairs, Ministry of Culture, YEI, TIKA and YTB. In addition, KDK drafted and performed public diplomacy programs directly itself. Units for University Programs, Political Communication activities, Media and Promotion Works were established to develop public diplomacy programs. The University Programs Unit carries out Public Diplomacy Panels, Foreign Policy Promotion Programs, Foreign Policy Workshops and Youth programs. The University programs carried out the new Turkish foreign policy. However, university programs were conducted mainly internally which caused the perception of propaganda. Youth programs were made to recruit foreign students and they carried out a successful public diplomacy. Africa and the Middle East were determined to be appropriate areas and the young people from these regions were the majority in the youth programs (Ekşi and Erol, 2018: 15). Political Communication activities included Country Meetings, Wise People Conferences, Europe Meetings, Panels and International Summit programs. Political communication activities are implemented at an academic level that renders them to be elitist. The inclusion of mainly academic people in communication activities limits the target audience in these kinds of activities. The Media and Promotion Works units conduct Reporters Delegations Program, International Press Information, Culture and Promotion activities. These drew the interest of the foreign press in Turkey and ensured first-hand and direct information. Within this framework, KDK was established to implement public diplomacy policy to influence international public opinion. In fact, the primary priority of KDK is, as stated in the established circulation, is to effectively tell the new story of Turkey (Kamu Diplomasisi Koordinatörlüğü, 2016 as cited by (Ekşi and Erol, 2018: 15).

The Yunus Emre Institute (YEI) and Cultural Diplomacy

Moving forward, the Yunus Emre Institute has become a cornerstone in the public diplomacy of Ankara due to the multifaceted role it plays, thus joining the race in line with the programs orchestrated by Franco Alliance, American Culture Centre, British Council, Goethe Institute, Confucius institute, Japan Foundation, Korean Cultural Centers and Russian Cultural Center. There is no doubt that public diplomacy is a recipe of soft-power instruments and its smooth execution depends on a "solid and incremental budget" better still "hard dollars." YEl is closing the gaps and robustly engaged in cultural diplomacy tenets such as, teaching Turkish as a foreign language, science diplomacy, and public diplomacy. 
The Yunus Emre Institute is a relatively young organization compared to its counterparts in some other countries. For example, the Alliance Française was established in 1883, the British Council in 1934, and the Goethe Institute in 1951. The Yunus Emre Institute (YEI), as the first Turkish organization to conduct cultural diplomacy, was established in 2009. The Institute aims at expanding the cultural influence of Turkey in the Balkans, Africa, and the Middle East. The Institute tries to achieve these objectives through introducing and promoting the Turkish language, history, culture, and art around the world. Though the Yunus Emre Institute operates as a non-governmental organization (NGO) according to its by-laws, it is affiliated with both the Ministry of Foreign Affairs and the Ministry of Culture. This makes it a government-sponsored organization rather than an independent enterprise. Moreover, the President of Turkey is the honorary chair of the Board of Trustees (Ekşi, 2019: 183).

In the field of IR data, the Institute of Cultural diplomacy pinpoints that Cultural diplomacy may be best be described as a course of actions, which are based on and utilize the exchange of ideas, values, traditions and other aspects of culture or identity, whether to strengthen relationships, enhance socio-cultural cooperation, promote national interests and beyond; Cultural diplomacy can be practiced by either the public sector, private sector or civil society." (https://culturaldiplomacy.org/index.php?en_culturaldiploamcy). Ekşi (2019: 183) purports that cultural diplomacy is defined as nurturing mutual understanding between states and their peoples through the exchange of ideas, knowledge, art, and other components of culture. More specifically, cultural diplomacy is the use of cultural activities for diplomatic purposes. It is the conceptualization of cultural relations between states in the context of public diplomacy at the individual and social level. Since culture and art have been used as a tool of foreign policy throughout history, it is understood that cultural diplomacy is not a new phenomenon. What is new today is the fact that the use of cultural activities to generate soft power through public diplomacy becomes much more important due to globalization as well as the advent of information and communication technologies. In short, cultural diplomacy has become a component of international public diplomacy. The constant reminder on national and international podiums by President Recep Tayyip Erdogan that the "World is bigger than five" hanging on the UNSC permanent fiefdom could take another dimension in the sense that, the global honeymoon on cultural diplomacy enjoyed by Franco Alliance, American Culture Centre, British Council, Confucius Institute and Russian Cultural Centers have witnessed new players and YEl is one of those ruthless actors.

The Reorganization of the Ministry of Foreign Affairs

The Ministry of Foreign Affairs that had implemented conventional diplomacy was restructured by a new organization law adopted after an interval of 16 years in order to adapt to the changing global system and transforming diplomacy. Accordingly, 10 new units were established within the ministry (Ünsal, 2013: 240 cited by Ekşi and Erol, 2018: 24). Those related to public diplomacy were Deputy General Directorate for Cultural Diplomacy, General Directorate for Information, Public Diplomacy Unit, Public Communication Department, Diplomacy Academy Department and Information Technologies Department, While, The General Directorate for Overseas Promotion and 
Cultural Relations was established as the unit responsible for cultural diplomacy. Deputy General Directorate for Cultural Diplomacy was also established. The objective of this unit was to promote the country via cultural activities; another duty was to provide coordination and diplomatic assistance for the Yunus Emre Institute and the overseas Yunus Emre Institute Turkish Culture Centers. Furthermore, the unit conducts the bilateral cultural agreements and exchange program agreements and under the JDP rule it extracted new cultural cooperation and exchange agreements with 29 countries in 10 years. In addition, the directorate organizes and supports comprehensive mutual activities abroad like "Culture Years", "Turkish Culture Weeks", "Turkish Culture Days", "Turkish Cinema Days" and "Turkish Film Weeks" (Ekşi and Erol, 2018: 25).

The General Directorate of Information

The duty of the General Directorate for Information was to carry out relations with the media, to ensure communication with the foreign public and to plan and execute the activities in public diplomacy as direct by the units of the ministry for public diplomacy. What is more, this unit had the duties of press information and public enlightenment, promotion of foreign policy to the national and international press. The Department for Diplomacy Academy conducts appreciated works to make the Turkish Ministry of Foreign affairs a center of interest and attraction with its "Foreign Young Diplomats Education Program" for foreign diplomats. Likewise, cooperation agreements were signed in the last 10 years between 38 countries and the Diplomacy Academy and 17 cooperation protocols and exchange agreements were signed in 2012 alone. The Department of Information Technologies carries out duties that make the ministry effective on social networks like Facebook, Twitter and You-Tube in various languages (Ekşi and Erol, 2018: 25).

The General Directorate of Overseas Promotion and Cultural Relations and the Deputy General Directorate of Cultural Diplomacy were established as the units to promote the cultural diplomacy of Turkey. The Ministry considers cultural diplomacy as one of the major components of the multidimensional foreign policy, and it engages in cultural activities abroad. In this context, the General Directorate has been assigned to conduct bilateral cultural relations and cultural exchange programs to achieve the goals of cultural policy. This policy has resulted in new cultural cooperation and exchange agreements with 29 countries during the JDP governments (The Ministry of Culture and Tourism, Cultural Agreements in Effects 2014). These agreements are an explicit indicator of efforts of reviving and strengthening cultural and political relations of Turkey with the world at large. In addition, the Directorate organizes and supports cultural events in various countries on a periodical basis (Ekşi, 2019: 181-182).

The Office of Public Diplomacy

The Public Diplomacy Coordination Office of the Prime Ministry was later renamed the Office of Public Diplomacy. The Coordination Office was established with a presidential memorandum on January 30,2010, under the Prime Ministry of Turkey for the purpose of influencing and guiding the international community (Presidential Memorandum, 2010). The structure of the Office consists of such units as the Media Works, Political Communication, Cultural Works, Corporate Works, and Project Development. The primary 
activities of the Office include organizing public diplomacy panels, foreign policy promotion programs, foreign policy workshops, and youth programs in Turkey (Prime Ministry Office of Public Diplomacy, 2014). On the other hand, the Office of Public Diplomacy presented a certain public diplomacy perspective by effectively explaining the new story of Turkey, engaging with diverse groups, and fulfilling operations of multisided communication. As such, the Office, as an organization in charge of public diplomacy, limits the Turkish public diplomacy to the action to promote the new story of Turkey to the global public in the most effective and comprehensive way (Kalın, 2011).

Turkish Cooperation and Coordination Agency (TIKA): Foreign Aid and Humanitarian diplomacy

Turkey adopted public diplomacy as a foreign policy in the 2000s; however, the soft power policy was implemented at the institutional level in the 1990s for the first time with TiKA. After the collapse of the Soviets in 1991, Turkey established the agency in 1992 as an institution to create soft power and to enlarge its influence in the Balkans, Caucasia and Central Asia (TIKA, 2016). TiKA was initially established as a technical aid agency and its purpose was to remove the separation created during the Soviet rule by reviving the sociocultural and historic ties between Turkey and those related communities where the Turkish language was spoken. For this purpose, TiKA realized cooperation projects in the field of economics, trade, socio-cultural areas and education. Further, Turkey provided the agency with great amounts of loans and grants for the development of the countries in the region it was targeting. This way TiKA served as a soft power institution that increases its effectiveness by filling the power vacuum that emerged in Balkans, Caucasia and Central Asia after USSR. Under the JDP government, TIKA was reorganized in 2011 within the framework of public diplomacy. Firstly, the word "development" in the name of the agency was replaced with the word "coordination" and the principle of coordinated work was done with the other public diplomacy institutions. In addition, the agency was supposed to work in coordination with the equivalent international organizations. To continue, the agency, which used to operate as a technical aid organization, was to adapt to the conditions of the current period and work on project base operations. On that account, foreign grant aids were transformed into projects instead of the old way of giving cash payment (Ekşi and Erol, 2018: 23).

Therefore, the organization and overseas coordination structure of the agency were restructured. Accordingly, the organization; and the structuring of the agency occurred in four regions following the areas of influence the Turkish foreign policy had, that is: Central Asia and Caucasia, Balkans and Eastern Europe, Middle East and Africa, East and South Asia, Pacific and Latin America Departments. TIKA previously had focused on the Balkans, Caucasia and Central Asia but during the JDP government its focus was transformed in line with the expansions of JDP foreign policy towards the Middle East, Africa and Latin America. This made the geographic activity of TIKA a global one considering the areas it covered. The agency had 12 foreign offices in 2002 and this number was increased to 50 in 2016 as an extension of the regional expansions in foreign policy. Additionally, it was Central Asia, which was the number one recipient of development aid, but now Africa and 
Central Asia have replaced it. According to the 2014 data, the project expenditure of TIKA for the Middle East and Central Asia reached USD 369 million. The money that the agency spent on global projects in 2014 reached USD 3.6 billion68. The countries that benefitted the most from the aid were Syria, Tunisia, Palestine, Somalia, Sudan, Afghanistan, Egypt, and Bosnia Herzegovina (TIKA 2016, cited by Ekşi and Erol, 2018: 23-24).

Moreover, the projects realized by the agency covered 28 countries between 1992-2002 while this number was more than 140 countries in years between, 2003-2014. In this way, TiKA became a prestigious institution for Turkey, when it came to implementing foreign aid and humanitarian diplomacy at a global level. Besides, TiKA contributed greatly to the international prestige of Turkey and gave it an image of aid providing country instead of an Aid receiving country. Thanks to these activities of the agency, the UN World Food Program announced Turkey as a rising donor country. In addition, TiKA became a milestone of the policy of Turkey when it comes to becoming a global actor. Likewise, by diversifying the Turkish foreign policy, the agency became both an indispensable instrument of foreign policy and the main institution for providing soft power for Turkey. In the final analysis, the activities of TIKA and its existence at a global level increased affection and sympathy for Turkey and ensured that it was viewed as a formidable global actor (Ekşi and Erol, 2018: 24).

TRT World, Daily Sabah and Anadolu Agency: Media Bellicose

TRT is a state television channel that carries out activities in the communication and information field of public diplomacy, and it was reorganized to run like CNN or BBC by way of establishing TRT World. The reason for this was to increase Turkey's power of mass communication instruments and new social media tools in global politics particularly during the 2000s. In addition, states had started to have an increasing tendency to use media as a diplomatic leverage and even as a weapon to ensure the support of the international public opinion when it came to international relations. Beyond that, the fact that global politics turned to an intellectual and ideological war caused different states to apply a new structuring in the field of media. In this context, CNN in the USA, BBC in Britain, Russia Today in Russia, CCTV in China, DW in Germany and Al-Jazeera in the Arab World were already well-positioned to wage these global media wars. Therefore, Turkey entered the international media wars environment with institutions like TRT World and Anadolu Agency (Ekşi and Erol, 2018: 25).

The understanding that Turkey needed global media instruments to help and explain and defend its policies; like the West had been doing, developed within the framework of public diplomacy under the JDP government. The international-ness of TRT have become the voice of Turkey regarding its country's story as an international instrument for political communication. Thus, TRT serves the function of being a communication bridge for Turkey with the world. These international channels are the face and images of Turkey as it was opening to the world and they were established as the main instrument of establishing a public opinion for the benefit of the country. Hence, in public diplomacy, the state used global TV channels broadcasting in different cultures to create public opinion and gain the support from the international community. Therefore, TRT has progressed towards becoming the indispensable communication instrument of the Turkish public diplomacy 
and one of the most effective tools to build Turkey as an attractive country and to build a positive perception of it (Ekşi and Erol, 2018: 26).

In a nutshell, the prominent importance of public diplomacy is based upon the "idea that a nation's reputation and relations with foreign publics have become a critical part of a nation's ability to carry out its foreign affairs objectives" (Fitzpatrick, 2007: 194). Therefore, Ankara's image as a secular democracy increases its feasibility to meticulously spearhead public diplomacy programs enveloped in her foreign policies vis-a-vis other countries and more especially with other Muslim countries particularly in the MENA region. The institutions which have been at the drivers' seat of Turkish public diplomacy, and the architects of these institutions such as former Foreign Minister Ahmet Davutoglu and a host of others did not only talk the talk but also worked the talk.

3. Old, Contemporary Gains and Setbacks

Public diplomacy is tantamount to meeting some grandeur successes and also setbacks when crafted and implemented by states. This section of the paper focuses on gauging some saintly-glories of Turkish public diplomacy accruing from old and contemporary wins and on those factors that stand as hindrances for the smooth execution of Ankara's public diplomacy.

Old Gains

Ankara has made fabulous gains since the coming of the JDP in power and the enforcement of its public diplomacy from 2010 till date has harvested brilliant results and these gains are multifaceted.

To begin with, since high and low politics at times complement each other, a groundbreaking political gain for Ankara in her public diplomacy is situated in her diplomatic and political mediation role in the Middle East. The Economist in 2010 reported that Turkey introduced mediation initiatives in its Middle East policy. As such, Turkey developed a mediation initiative based on sovereignty and control of the Golan Heights between Syria and Israel. Moreover, Turkey proceeded to mediate between Israel and Hamas while playing a role of facilitator for the integration of Hamas into the politics of region and for consensus with Al Fatah. Particularly its achievement of solving the problem of Israeli Soldier Gilad Shalit held hostage by Hamas, the Economist magazine detailed the mediation initiatives of Turkey particularly President Erdogan as a success story under the headline of "the Great Mediator."

Another symbolic angle that stands out as a past glory for Turkey's global image in her public diplomacy largess stems from the problematique associated with the "Clash of Civilizations" just like globalization. The JDP leaders did not keep the model country rhetoric limited within the Middle East but also tried to utilize it for the leadership of the Muslim world. The Initiative of Alliance of Civilizations, known also as UNAOC, started in 2005 under the auspices of the UN Secretary-General Kofi Annan, President Erdogan, and the Spanish Prime Minister José Luis Rodríguez Zapatero. It was used by the JDP government as a global public diplomacy opportunity to try and to become the speaker of the Muslim World. The historic context of the initiative was based upon the discussions of the "Clash of Civilizations" which became a keystone in the agenda of the international public opinion during the 1990s. The clash of civilizations argument was brought about to 
the international public by the article of Huntington and it was depended upon the assumption that the essential dynamics of the post-Cold War conflict would be the conflicts between cultures and religions as a new threat (Huntington, 1993 cited by Ekşi and Erol, 2018: 26). Huntington established his argument mainly on the conflict between the West and Islam rather than all other civilizations. As a result of the escalating controversy and concerns on clash of civilizations, in 1998 UN General Assembly declared the year 2000 as the "Year of Dialogue between Civilizations" upon the proposal of Iran's President Khatami, UN 1998 (ibid).

In addition, YEI has made remarkable progress in spearheading and putting Ankara on the global stage when it comes to cultural diplomacy. The Yunus Emre Institute is a worldwide non-profit organization created by the Turkish government in 2007. Named after the famous 14th-century poet Yunus Emre, it aims to promote the Turkish language and culture around the world. It should be noted that, the first center of the Institute was opened in Bosnia Herzegovina on 17 October 2009 with the name "Sarajevo Yunus Emre Turkish Cultural Centre" and the institute started to spread in the Balkans. Likewise, the Minister of Foreign Affairs Davutoğlu said in his speech at the opening of the Sarajevo cultural center, which was, the first cultural center, that "it is not a coincidence that the first center is opened in Sarajevo. This is a reasoned decision that we concluded after long thoughts about it" (YEE 2009). We understand that the first area of expansion for the institute was to be the Balkans. Just after that, the second center was opened in Tiran, the capital of Albania, on the $11^{\text {th }}$ of December 2009.

As of 2014, there were $11^{\text {th }}$ Institute centers in the Balkans: Sarajevo, Tiran, Foynitsa (opening date: $11^{\text {th }}$ October 2011), Mostar, Shkodër (20th October 2012), Pristina (26 th August 2011), Ipek (20 March 2012), Skopje (26 th March 2010), Bucharest (14 November 2011) and Constanta (14th November 2011). After Sarajevo, the Institute opened its first center in the Middle East. Specifically in Cairo, Egypt on the $3^{\text {rd }}$ of March 2010 and has built 7 centers in the Middle East and Africa as of 2014: Alexandria (27 th April 2013), Beirut

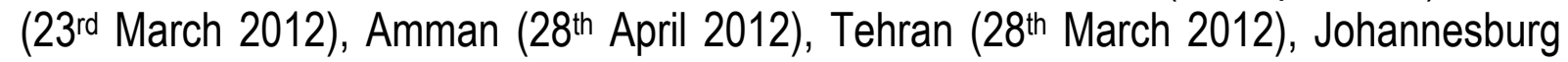
(2017), South Africa (December 2012) and Rabat (March 2013). On the other hand, the Yunus Emre Turkish Cultural Centre in Damascus, the capital of Syria, which began to operate on the $15^{\text {th }}$ of December 2010, was closed due to the civil war and deteriorating relations between the two countries. Six centers were opened in Eurasia and Far East: Tbilisi (31st of May 2012), Baku (2013), Astana (26 th May 2010), Kazan (October 2012) and Tokyo (20 ${ }^{\text {th }}$ October 2011). Eight centers were opened in Europe: Brussels (18 $8^{\text {th }}$ October 2010), London (9 November 2010), Budapest (June 2013), Warsaw (20th June 2011), Berlin (2014), Paris (2014), Amsterdam (2014) and Rome (30th January 2014). In total, 38 centers have been opened in 30 countries in 7 years from 2009 to 2016 since the establishment of the Yunus Emre Institute. The Institute plans to open cultural centers in cities like Beijing, Washington, New York, Kuala Lumpur, Delhi, Kuwait, Qatar, Dubai, Madrid, and Athens in the years 2017-2018 (YEl, 2014 Report).

Furthermore, a symbiotic public diplomacy gain made by Ankara rest in the field of education and award of scholarships to international students. In this light, YTB combined different higher education scholarships that were granted to international students by 
various state agencies under an individual foundation called "Turkey Scholarships". The first implementation of the Turkey Scholarships was done in 2012, and can be considered as one of the greatest public diplomacy activities of Turkey and equivalent to the Fulbright scholarship in the U.S. Likewise, the scholarships granted to foreign students by several state agencies like Turkish Council of Higher Education (YÖK), the Scientific and Technological Research Council of Turkey (TUBITAK) and TIKA used to be independent of each other and without any programs under public diplomacy. However, since 2011, YTB guides these scholarships to make Turkey a base of education through the public diplomacy perspective. These scholarships are channeled into categories according to the tendency of the Turkish foreign policy usually towards Turkish speaking countries (Central Asia), Balkans, Africa, Harran (Middle East), Estuary (South Asian countries), Bosporus (India, China, Japan, South Asia, Brazil) and Anatolia (Afghanistan, Somali). Stunningly, the demand for Turkey scholarships increased rapidly from 2003 to 2016. Initially, YTB had a demand for scholarships around 90 thousand annually, while there were 155 thousand applications from 182 countries for the Turkey Scholarships between 2015 and 2016. Scholarships were granted to more than 50 thousand students between 2012 and 2016. In conjunction with the increase in scholarships, the number of foreign students in Turkey increased as well. Thus, Turkey entered the international education market as a new player (Ekşi and Erol, 2018: 36).

Moreover, the Soft Power Index (SPI) can give us more nuanced information about Turkey's soft power (McClory 2019). The SPI annually ranks the Top 30 countries according to their soft power scores since 2015. Turkey's presence in the ranking varies across years. The SPI is composed of a variety of sub-indexes. The 'digital' and 'engagement' aspects of soft power have played a decisive role in promoting Turkey onto the list. While the engagement sub-index has metrics like 'the number of embassies/high commissions a country has abroad, membership of multilateral organizations, and overseas development aid contributions', the digital sub-index '... captures the extent to which countries have embraced technology, how well they are connected to the digital world, and their use of digital diplomacy through social media platforms' (McClory 2019, 27-28).

In conclusion, the above expatiated past glories stamina from Ankara's mediation role, the debates and debunks surrounding the myth of the "clash of civilization", YEI and YTB aren't the sole organs that are pivotal in this mission since there exist other bodies that make gigantic moves that have catapulted the public diplomacy of Ankara so excellently.

Contemporary Gains

In terms of the recent gains scored by the TPD, one of such gains lies in its humanitarian largess during the Covid-19 pandemic era. In dishing out and showing its humanitarian prowess during Covid-19 period, Turkey stood out as one second to none in assisting states bleeding profusely. In line with those state institutions that were at the forefront of providing assistance, Buğra (2021: 3) stated that these institutions are TIKA (Turkish Cooperation and Development Agency), Turkish Red Crescent, and the Ministry of Health, provided protective equipment, respectively, followed by testing kits (48), medical devices (34), others (30), nutrition (26), and medical drugs (8). The 'others' category comprises the 
renovation and building of hospitals, hospital beds, equipment for intensive care units, and medical vehicles, such as ambulances etc.

By the same token, diagnostic materials were also important to identify and thereby trace the movement of patients. To this end, Turkey has provided recipients with testing kits and PCR machines. In this respect, it should be noted that the Turkish state in partnership with the private sector started to produce breathing devices in late March 2020. While the country was providing these machines for national use, it also supplied these domestically-produced mechanical ventilators to countries that could not meet the heavy demands of patients particularly in intensive care units. Cross-continent variation shows that Asia and Africa enjoyed more Turkish medical aid than others, with 22 countries in each continent. They are closely followed by Europe, with 20 countries. On the other hand, the Americas seem underrepresented. While 5 countries in South America have received medical aid from Turkey, only 3 countries in North America have done so: the United States (US), Mexico, and Haiti. The TurAid dataset also shows that only 27 cities are specifically referred to in the news. Most of these cities are in Muslim-majority countries, or countries with a considerable Muslim population. For instance, Turkey has sent multiple batches of medical aid to Novi Pazar, which is a Muslim-majority city in Serbia (Anadolu Agency 2020b).

Beneath Turkey's long-standing aid strategy, there is a clear interplay between economic pragmatism and humanitarianism (Buğra, 2021: 3).

Recent gains in Turkish public diplomacy can be seen in areas such as cultural events which are often in the form of concerts and arts exhibitions, study of Turkish language, opening of libraries and other information- which draws public opinion to be interested in Ankara as it showcases the richness of the Ottomanism and New-Turkey. The Hurriyet Daily News chronicled an article with the headline "Istanbul's Pilevneli Gallery presents Refik Anadol's Latest Exhibition". The article opens with Istanbul's Pilevneli Gallery is presenting media artist Refik Anadol's new solo exhibition titled "Machine Memoirs: Space," introducing a new body of works. Located in Beyoğlu's district Dolapdere quarter, the gallery will continue to display Anadol's work till April 25. Speaking to the state-run Anadolu Agency, Anadol said that he always brought his best ideas to Turkey. "I have developed very meaningful relationships in all the works I have done in Istanbul for 10 years. I realize my best ideas here, such as the 'Sounds of İstiklal Street' project in 2011, 'Archive Dream' or 'Melting Memories,'” he said. Referring to the keen interest of especially young people in digital arts, Anadol said: "My dream as an artist was the possibility of making art for every age, every culture and every person. This is why I work with a team of 14 people who can speak 14 languages and represent 10 countries. In this sense, universality is one of my biggest concerns. But I see that especially my young friends are interested in artificial intelligence, space, big data and foreseeing new experiences of the future." Stating that the high interest of young people of Turkey puts different responsibilities on him, Anadol said: "Within the framework of the exhibition, I dream of free workshops on artificial intelligence as much as I can. To be honest, I did not expect such interest, and I would like to turn this effect into a positive sharing. For this reason, I presented all data in open source at the exhibition. I put up screens where visitors can see 
the name and method of the algorithm used." (hurriyetdailynews.com/istanbuls-pilevneligallery-presents-refik-anadols-latest-exhibition). In this new era of mass communication where there is "information from around the globe to policymakers and the general public alike, often in real-time, 24 hours a day, seven days a week" (Constantinou, Der Derian, 2010: 152), states are no longer able to control the flow of information. TRT World, Daily Sabah and Anadolu Agency media outlets have become rival media global competitors to renowned media outlets like CNN, WION, BBC, Aljazeera, France 24, The Economist, Washington Post. TRT World has become pragmatic and robust in its coverages, it kept an eye on the Covid-19 from the early stages till date with daily updates, it reported daily on the recent Israeli-Palestinian standoffs and not forgetting the security dilemma in Afghanistan. TRT World which broadcast mainly in English has been able to penetrate and win the hearts of viewers, it invites experts, runs debates, digital sessions and operates social media pages on Instagram, Facebook, Twitter, Linkedln hence meeting and shaping the narratives in favour of Turkey's public diplomacy. Anadolu Agency, reports in more than 10 languages and Daily Sabah have extensive coverage in Arabic and English. These media outlets operating under the stewardship of Ankara's interest were central reporting on Turkey's humanitarian assistance to needy States and other programs during the dark days of Covid-19. In fact, in today's media war, prominent names like CNN, BBC, etc. can no longer lay claim of global monopolization of information and chartering the course of their respective states because other competitors have emerged such as TRT World, Anadolu Agency and Daily Sabah. Therefore, communication activities are considered as political communication activities limited to the academic aspect of public diplomacy. Country meetings bring together experts of the think tanks and researchers around the world with their counterparts in Turkey. Moreover, these meetings aim to build a ground for systematic communication and connection among local and foreign researchers, academicians, journalists, and politicians. However, the scope of the Office has almost been narrowed to inward-oriented activities. Besides, one may argue that the Office has an approach to public diplomacy in a way to present itself as merely a tool to influence the international community (Ekşi, 2019:182). Building on this point, Turkey has been able to ensure that Think Tanks such as, The Foundation for Political, Economic and Social Research/Siyaset, Ekonomi ve Toplum Araştırmaları Vakfı (SETA) is a policy think-tank based in Ankara, Turkey, Turkish Asian Center for Strategic Studies/Türk Asya Stratejik Araştırmalar Merkezi (TASAM), founded in 2003 as an NGO and Think Tank, is an international scientific research, The Center for Middle Eastern Studies/Ortadoğu Araştırmaları Merkezi (ORSAM) was established in January 2009, just to name a few are central in the public diplomacy of the Country spearheading the organization of both on and offline academic, scientific research programs bringing students, young professionals and experts in the field of international relations, foreign policy, developmental and global studies. These Think Tanks also operate their own social media pages and websites with academic publications and daily updates on recent global affairs.

In addition, the Turkish Scholarship/Türkiye Bursulari under the canopy of Turks Abroad and Related Communities/Yurtdışı Türkler ve Akraba Topluluklar Başkanlığı (YTB) from its full-fledged operation in 2012, YTB has been ruthless in executing Turkish public 
diplomacy. YTB yearly Scholarship scheme can now match prestigious scholarship schemes like DAAD-Germany, Fulbright-USA, Commonwealth-UK, CSC-China, KSGPSouth Korea, MEXT-Japan etc. The Presidency for Turks Abroad and Related Communities (YTB), which was established on April 6, 2010, has undertaken the task of coordinating the work for our citizens abroad, our sister communities and our international scholarship students studying in Turkey, and developing the services and activities in these areas. With the efforts of our Presidency, relations with both our citizens living abroad and sister communities are strengthened, and closer economic, social and cultural relations are established. Our Turkish Scholarship students are; They become our volunteer ambassadors around the world (ytb.gov.tr/kurumsal/baskanligimiz-2).

YTB has been able to forge scholarship partnership with Islamic Development Bank (ISDB) and has curved a comfortable arena for itself thanks to technology and operates a website and prominent social media handles giving daily updates about its programs and the stamina of international students and alumni for example on its Instagram account, it has 976 posts, more than 110k followers. As of August 2021, the YTB website shows that they are 3730 Türkiye scholarship Alumni in HealthCare, 1830 in Natural Sciences, 920 with Education Degrees, 506 Alumni in Architecture, 5148 in Administrative Sciences, 5170 in Engineering, 483 in History, 1246 in Media Studies, 2874 in Political Science and International Relations worldwide including Alumni social media platforms. More so, YTB organizes competitive free summer school, international student awards in varied categories such as projects, reports, literature, artificial intelligence, media and communication, culture and art sessions etc. It is postulated that just as Alumni of Fulbright, Commonwealth is warmly receptive to the US and UK, thus, they will do same for Turkey in their respective countries especially those who would be heralding the state apparatuses. Although scholarships have been provided within the framework of bilateral agreements signed with other states, especially since the 1960s, the international student policy of our country was systematized for the first time in 1992 with the encouragement of the late President Turgut Özal, and the study called "Great Student Project" was initiated. Since the beginning of the 2000s, Turkey's great progress in every field, from foreign policy to culture, from economic development to social policies, has also been reflected in the international education paradigm, and important steps have been taken in this field (ytb.gov.tr/uluslararasi-ogrenciler/turkiye-burslari). YTB's presidents have been shepherding the welcoming and graduation ceremonies of international students with a grandeur ceremony that always emphatically organized. While Türkiye Scholarships received around 10 thousand applications in 2012, when it started to be implemented, this number increased to over 100 thousand in 2017. At the same time, the number of countries receiving applications has almost doubled. In 2019, a record number of applications were made to Türkiye Scholarships with 145 thousand 700 applications from 167 countries of the world. According to recent updates on the YTB website, clearly states that "our country has recently; With the number of universities, number of research centers, number of academicians and internationalization dimensions, the field of higher education has experienced a great change. In the last 10 years, the number of international students studying in our higher education institutions has increased by 75 percent, and according 
to current figures, our country has become one of the countries that host the most international students in this field, with approximately 148,000 international students, 25 thousand of whom are on scholarships. Our country aims to host 200 thousand international students in 2023 (ytb.gov.tr/uluslararasi-ogrenciler/uluslararasi-ogrencihareketliligi).

Rooming around the "Clash of Civilization", Turkey has used this purported saga of Huntington in changing the narratives accruing from classical debates in spearheading determined solutions over the polarization of Islam and Christianity/East-West dichotomy and the Muslim and Western standoffs in initiating ground-breaking programs programs such as Alliance of Civilization, ICYF Diplomacy Academy, Young Volunteers Programs, Youth Global Action Countering Islamophobia, Global Peace Summits, Future Leaders Conference Model United Nations, Balkan Youth Forum, Youth Engagement with Religion and Faith in the $21^{\text {st }}$ Century among other programs which brought youths across the globe from all religious beliefs, civilizations and cultures. Istanbul is hosting the Islamic Cooperation Youth Forum office and all these programs have won Ankara more friends and the millions of tourists who made they way to Turkey's tourist cities during this summer amid of the Corona-virus will best tell a story about the hospitality of Turkey worldwide.

Setbacks

There is no country whose public diplomacy has not met backlashes and sometimes total failure due to inadequate planning and lack of resources etc., even the US which has a formidable record in public diplomacy has had daunting times. Turkey's implementation of her public diplomacy has some limitations particularly owing to security concerns and other factors.

To begin, picking from the institutional repositioning and offices geared towards driving Turkey's public diplomacy, Ekşi (2018: 183) argued that the Office interprets Turkey's public diplomacy from a very narrow perspective in that they aim at explaining the country's position but not listening to others and that its activities somewhat neglect the cultural, foreign aid, and lobby aspects of international public diplomacy.

In addition, the high and low tides in the relations between Yerevan and Ankara over Genocide claims and the recent Nagorno-Karabakh conflict are stalemates in Turkey's public diplomacy. These two issues have caused a diplomatic rupture between both states and normalization is far-fetched for now. The tensions between Armenia and Turkey centers on lengthy historical dichotomous lines and reconciling these two states will require a series of historical normalizations talks and sincere dialogue with such meetings taking place on both soils and a third party will be needed as well. A good rapprochement for both states to once more enjoy a one-time honey-moon will rest on the shoulders of public diplomacy not forgetting exchanges and visits of Armenia and Turkish diasporas as well to each other's country.

A cardinal setback that stands as a stumbling block for Ankara's public diplomacy stems from the Arab Spring of 2010-2011 and the spillover effects. Turkey changed its position when the Syrian civil war took a different dimension. Sharing borders with Syria, the influx of more than 4.5 Syrian refugees into Turkey signaled those resources meant for Ankara's public diplomacy had to be rationed to meet the needs of the refugees with Turk Kizilay 
and other donors doing tremendous work. The fight against PKK and other terrorists' threats on Turkish borders for long especially within these years of Ankara's public diplomacy adds to the pile of challenges since it limits its spread and penetration. The most recent threats to Turkish public diplomacy include the security dilemma in Afghanistan with the Taliban's re-ascension into power and the wildfires and floods. In fact, if there is a factor that has caused a crack and limited Turkish public diplomacy and soft power which people like Ahmet Davutoğlu never envisaged that has warranted Turkey to use hard power, it is the Syrian debacle.

The last factors that have stood as a hindrance to Turkey's public diplomacy are the Europeanization of the EU and UEFA Champions League Finals. Despite Turkey's compliance to the ascension rules and regulations of the European Union way back in the 2000s she has not gained full-fledge membership and Croatia has come from behind to gain admission into the EU. The reasons highlighted for the non-acceptance of Turkey are constant tension with Greece and the Cyprus Affair etc. The withdrawal of the UEFA champions league football jamboree finals twice in 2020 and 2021 respectfully from Ataturk Olympic Stadium in Istanbul-Turkey could be termed as "Politics of Covid" and the UK spearheaded the 2021 final withdrawal over the safety of her citizens is a blow to Ankara's public diplomacy after grandeur preparations were made. Hopes by Turks to be made by UEFA for an award of another final expected soon.

Prospects of Turkish Public Diplomacy prior to 2023

This portion of the article is dedicated to what is forthcoming and expected results for Ankara's public diplomacy especially prior to a Centenary of Turkey's Independence in 2023. Let's now focus on those points that this paper envisaged as the likelihood for a more dynamic and robust Turkish public diplomacy.

Firstly, the prestigious YTB scholarship scheme would be able to distinguish and its outputs speak for itself matching up with National Merit Scholarship (Academic Excellence) Scholarships (Study at the University of Oxford), Schwarzman Scholarship (Graduate study at Tsinghua University in Beijing), Winston Churchill Scholarship (Study in STEM at Churchill College, Cambridge University). Despite an expected rise in the number of foreign students to 200 thousand in 2023 , the scholarship has to be healthy enough in the line of the stipend, internships and more. This can only happen when internal ramifications within the YTB/Turkish Scholarship board with the approval of constitutive actors and institutions that matter do a succinct evaluation of the system.

Secondly, the institutions responsible for Turkish public diplomacy be it governmental and non-governmental organizations as TIKA, YTB, SETA Foundation, ORSAM, TASAM, Turkish Heritage organization, TUBITAK, TURAID, YEI, Office of Public Diplomacy, General Directorate of Information and the Ministry of Foreign Affairs etc. are envisaged to robustly adapt with the changing dynamics of globalization and shifting patterns of public diplomacy accruing from the competition and soft power implementation and Ankara will make a tremendous push in meeting its foreign policy needs and its public diplomacy agenda with impeccable results on the way and most significantly with a grandeur celebration in 2023.

Thirdly, though TRT World is just six years old, it has made a tremendous breakthrough 
in the media world matching its fist of the big guns like CNN, BBC, Aljazeera, WION etc., in fact these ancient media barons have lost the global media monopoly because of newcomers. Though TRT is solely a state-owned media with the slogan as "Where News Inspires Change", it broadcasts all round the clock in English and it operates under the rubrics of the Turkish Radio and Television Corporation (TRT) and its main headquartered in Istanbul with subsidiary stations in Washington DC, London and Singapore. Apart from providing global news and current affairs, TRT World keeps providing us with the ins and outs of Covid-19, is covering the recent tensions between Israel and Palestine, the security dilemma in Afghanistan, the Tigray saga and a lot more which the renowned media outlets have chicken-out proving little or no report. It is a member of the Association of International Broadcasting and its website and social media handles.

Furthermore, prior to the outbreak of a global pandemic, it organized the, 2017, 2018 and 2019 TRT World Forum in physical, in 2020 it went digital and this year's $20215^{\text {th }}$ edition would be digitally baptized under the theme "Power and Paradox: Understanding the Grand Strategy in the $21^{\text {st }}$ Century". It also operates TRT Digital Series focusing on global topical issues such as Climate Change, security, US-Turkey relations, economic matters and socio-cultural issues taking advantage of technology via its Facebook and Instagram accounts bringing the finest research brains and experts together and those with conflicting views during panel discussions and debates. Despite the gains and its relative youngness on the global media landscape as compared to the old hands, TRT World has to undertake measures in improving its global view-ship, for example it has 99kFacebook followers, Instagram-624k, Youtube-1.37M followers, Twitter-412k followers which is quite impressive but it needs to spread its offices in Africa, Latin America, the Balkans, Caucasian, Eastern Europe etc.

Conclusion. This article has penned down those institutions that are manning Turkish Public diplomacy such as YEI, TIKA, YTB etc., it made an appraisal on Turkish public diplomacy within a decade bringing to light past, contemporary gains and shortcomings as well. The paper then evolved around the prospects that await Turkish public diplomacy ahead of the 2023 Centenary Independence Celebration citing the role of TRT World as an important player in this expectation. It is pivotal to consider that for public diplomacy to be considered successful, soft power should be accompanied by economic prowess that will metamorphose into vibrant persuasive power. Within a decade, Turkish public diplomacy seems to have witnessed low and high tides however it keeps maturing as the years unfold. There is no doubt that the JDP leadership, institutions and actors in Ankara's public diplomacy initiative from 2010 should be applauded for haven nurtured and implemented its public diplomacy after ascending power not focusing solely on the Middle East but has mapped out other regions globally, harvesting excellent results and off course thanks to the "Strategic Depth" Doctrine of Foreign Minister Davutoglu that Turkey has now mastered the public diplomacy terrain and has a great interest page in dominating global public diplomacy arena with little or no resistance from other states, particularly in an unpredictable MENA Region. 


\section{References}

1. Bekim, B., Ngadhnjim, B., and Fjolla, N., (2013). Kosovar Public Diplomacy. https://doi.org/10.21113/iir.v3i1.106/ Vol. 3 No. 1 (2013).

2. Buğra, G. (2021). Foreign aid during the COVID-19 pandemic: Evidence from Turkey. Southeast European and Black Sea Studies, DOI: 10.1080/14683857.2021.1900668.

3. Büyüktanır, D. (2018). Public Diplomacy Activities of TÜSIAD and MÜSIAD During the AK Party, Gazi Akademik Bakış, Winter 2018, Vol. 11/23: 73-98.

4. Constantinou, C., Der Derian, J., (2010) "Sustainable Diplomacies", Palgrave Macmillan, Basingstoke.

5. Davutoğlu, A. (2008). Turkey's Foreign Policy vision: An assessment of 2007. Insight Turkey, 10(1), 2008, ss. 77-96.

6. Ekşi, M. and Erol, M. S. (2018). The Rise and Fall of Turkish Soft Power and Public Diplomacy. Academic View; Volume 11, Issue 23, Winter 2018.

7. Ekşi, M. (2019). Public Diplomacy and Soft Power in Recent Turkish Foreign Policy. T.C. Anadolu University Publication No: 3944 Faculty of Open Education Publication No: 2733 Turkish Foreign Policy I E-Isbn: 978-975-06-3643-1.

8. Fitzpatrick, K., (2007) "Advancing the New Public Diplomacy: A Public Relations Perspective", The Hague Journal of Diplomacy, Vol.2, pp.187-211.

9. Gilboa, E. (2008), 'Searching for a Theory of Public Diplomacy', The Annals of the American Academy of Political and Social Science, Vol.616 No.1, pp. 55-77.

10. Golan, G., (2013) "An Integrated Approach to Public Diplomacy", American Behavioral Scientist, Vol.57, No.9, pp.1251-1255.

11. Handelman, S., (2012) "Two Complementary Settings of Peace-making Diplomacy: Political Elite Diplomacy and Public Diplomacy", Diplomacy and Statecraft, Vol.23, No.1, pp.162-178.

12. https://culturaldiplomacy.org/index.php?en_culturaldiplomacy

13. https://www.yee.org.tr/tr/kurumsal/yunus-emre-enstitusu

14. https://www.hurriyetdailynews.com/istanbuls-pilevneli-gallery-presents-refik-anadols-latestexhibition-163339

15. https://www.ytb.gov.tr/kurumsal/baskanligimiz-2

16. https://www.yee.org.tr/tr/yayin/2014-faaliyet-raporu

17. https://www.ytb.gov.tr/uluslararasi-ogrenciler/turkiye-burslari

18. https://www.uscpublicdiplomacy.org.

19. https://www.ytb.gov.tr/uluslararasi-ogrenciler/uluslararasi-ogrenci-harekettiligi

20. http://culturaldiplomacy.org/academy/pdf/research/books/soft_power/The_New_Public_Diploma cy.pdf

21. Jeffrey, H. "Twenty years after Huntington's 'Clash of Civilizations", 2013, http://www.eir.info/2013/02/10/twenty-years-after-huntingtons-clash-of-civilisations/.

22. Kalın, İ. (2011). Soft Power and Public Diplomacy in Turkey, Perceptions, Vol. XVI, No. 3: 5-23.

23. KDK, "Vision \& Mission", Kamu Diplomasisi Koordinatörlüğü, 2016.

24. Melissen, J., ed. 2005a. The New Public Diplomacy: Soft Power in International Relations.Basingstoke: Palgrave Macmillan.

25. McClory, J. (2019). The Soft power 30: A Global Ranking of Soft Power. London: Portland Communications. available online at https://softpower30.com/wpcontent/uploads/2019/10/ The-Soft-Power-30-Report-2019-1.pdf

26. Nye, J. (2008). "Public Diplomacy and Soft Power." The Annals of the American Academy of Political and Social Science 616.

27. Ömer, T. (2012), "Turkey: The New Model?", The Brookings Institute, 2012.

28. Roselle, L., Miskimmon, A., O'Loughlin, B., (2014) "Strategic narrative: A new means to understand soft power", Media, War and Conflict, Vol.7, No.1, pp.70-84.

29. Samuel, P. H. (1993) "The Clash of Civilizations", Foreign Affairs, 27(3), 1993, ss. 22-49. 
30. Snow, N., M. Taylor, P., (2008). "Routledge Handbook of Public Diplomacy", published in association with the USC Center on Public Diplomacy at the Annenberg School based at the University of Southern California, first published 2009, this edition published in the Taylor \& Francis e-Library.

31. TiKA Tarihçe, "TiKA tarihçemiz", 2016.

32. TIKA Rapor, TIKKA Türkiye kalkınma yardımları 2014 Raporu, http://www.tika.gov.tr/upload/publication/KYR\%20\%202014.PDF, s.14.

33. "Türkiye bursları'na 155 bin aday başvurdu", Hürriyet, 2015, http://www.hurriyet.com.tr/ turkiyeburslarina-155-bin-aday-basvurdu-28667790.

34. The Economist, "The Great Mediator", The Economist, 2010, http://www.economist.com/ node/16847136.

35. The UN, "Assembly Proclaims 2001 United Nations year of dialogue among Civilizations, expressing determination to facilitate international discussion", The United Nations, 1998, http://www.un.org/press/en/1998/19981104.ga9497.html.

36. The UN, "Assembly Proclaims 2001 United Nations year of dialogue among Civilizations, expressing determination to facilitate international discussion", The United Nations, 1998, http://www.un.org/press/en/1998/19981104.ga9497.html.

37. Traub, J., "Turkey rules", New York Times, 01.03.2011, http://www.nytimes.com/2011/01/23/magazine/23davutoglu-t.html.

38. Ünsal, Ü. (2013), "T.C. Dışişleri Bakanlığı ve yeni teşkilat kanunu"., Türk Dış Politikası: Kurtuluş Savaşından Bugüne Olgular, Belgeler, Yorumlar, Baskın Oran (ed.), İstanbul: İletişim Yayınları, 2013, s. 240.

39. Yunus Emre Enstitüsü (2009). Yunus Emre Bülteni, Vol. 2, December 2009, http://www.yee.org.tr/media/_bulten/pdf/aralik_2009.pdf

Бюлент Акма, профессор

Университет Анадолу, Туреччина

Теканг П. Квачух, аспірант,

кафедра політології і

міжнародних зв'язків,

Університет Анадолу, Туреччина

\section{ТУРЕЦЬКА ГРОМАДСЬКА ДИПЛОМАТІЯ ЗА ОСТАННІ ДЕСЯТИЛІТТЯ: ОЦІНКА І ПЕРСПЕКТИВИ}

Народження національних держав після Вестфральського договору 1648 p. означало домінування їх у міжнародних відносинах. Кінець Першої та, зокрема, Другої світової війни прискорив зміну парадигми в глобальних напрямках, коли cвіт керувався суперництвом між США та СРСР під час "холодної війни". Народження сучасної Турецької Республіки в 1923 році як залишку неіснуючої Османської імперії стало однією з найуспішніших держав, чиє геостратегічне положення $\epsilon$ величезною перевагою в ї̈ публічній дипломатії, яка намагається максимально використовувати свою силу. Ця стаття зупиняється на тих інституціях, які відіграють ключову роль у катапульті турецької публічної дипломатії, зокрема з 2010 до середини 2021 року. Крім того, ия робота спрямована на розгляд останніх досягнень за 10 років турецької громадської дипломатії та звертає увагу на негативну реакцію та перспективи турецької громадської дипломатії. У цій статmі з ясувалося, що важливою установою, яка 
провіщає публічну дипломатію Туреччини, є Міністерство закордонних справ Туреччини, а престижна програма стипендій турецького уряду є однією $з$ найбільших досягнень Туреччини. Величезний дефріцит турецької громадської дипломатії залежить від незахищеності на їі кордонах. Нарешті, передбачувану перспективу можна помітити із зростанням конкурентного характеру TRT World у глобальному медіа-ландшафрті. У цьому документі робиться висновок, що публічна дипломатія Анкари буде більш надійною до сторіччя ії незалежності в 2023 році на основі ії інститутів, останніх досягнень і цілей зовнішньої політики.

Ключові слова: оцінка, м'яка сила, публічна дипломатія, перспектива, Туреччина. 